\title{
POSSIBILITY OF INCREASING MICRONUTRIENT CONTENTS IN POTATO TUBERS WITH FOLIAR APPLICATION OF TITANIUM
}

\author{
WADAS, W. ${ }^{*}$ - KALINOWSKI, K. \\ Siedlce University of Natural Sciences and Humanities, Faculty of Natural Sciences \\ Department of Vegetable Crops, B. Prusa 14, 08-110 Siedlce, Poland \\ *Corresponding author \\ e-mail:wanda.wadas@uph.edu.pl; phone: +48256431296 \\ (Received $14^{\text {th }}$ Dec 2018; accepted 22 ${ }^{\text {nd }}$ Feb 2019)
}

\begin{abstract}
This paper analyses the effect of titanium foliar application on the $\mathrm{Fe}, \mathrm{Zn}, \mathrm{Mn}$ and Ti content in early crop potato tubers. The titanium source was the plant growth stimulant Tytanit ${ }^{\circledR}$ ( $8.5 \mathrm{~g}$ Ti per litre). Tytanit ${ }^{\circledR}$ was applied once at the leaf development stage (BBCH 14-16) or at the tuber formation stage (BBCH 41-43) and twice at the leaf development and tuber formation stages, at the dose of $0.2 \mathrm{~L} \mathrm{ha}^{-1}$ or $0.4 \mathrm{~L} \mathrm{ha}^{-1}$ in each treatment. Potatoes were harvested 75 days after planting (the end of June). Following Tytanit ${ }^{\circledR}$ application, the content of Fe was higher by $6.150 \mathrm{mg} \mathrm{kg}^{-1}$ and Mn by $0.409 \mathrm{mg} \mathrm{kg}^{-1}$ of dry matter. Titanium foliar application did not affect the content of Zn, whereas the content of Ti was higher by 0.364 $\mathrm{mg} \mathrm{kg}^{-1}$ of dry matter. The dose and date of Tytanit ${ }^{\circledR}$ application slightly affected the content of Fe. The content of Mn was greatest with a single Tytanit ${ }^{\circ}$ application at the tuber formation stage at the dose of $0.2 \mathrm{~L} \mathrm{ha}^{-1}$, whereas the Ti content was greatest with a double Tytanit ${ }^{\circledR}$ application, at the leaf development and tuber formation stages, at the dose of $0.2 \mathrm{~L} \mathrm{ha}^{-1}$.
\end{abstract}

Keywords: early potatoes, plant growth stimulant, Tytanit ${ }^{\circledR}$, nutritional value

\section{Introduction}

Although micronutrients are used in relatively small amounts, they play an important role in plant metabolism and in the human body assisting in the prevention of many diseases and the maintenance of good health. On the other hand, an excessive amount of some micronutrients can be toxic to a human (Welch, 2002; Martinez-Ballesta et al., 2010; Soetan et al., 2010; Al-Fartusie and Mohssan, 2017; Nieder et al., 2018). The Recommended Dietary Allowance (RDA) of Fe for men and postmenopausal women is $8 \mathrm{mg}$ and for premenopausal women $18 \mathrm{mg}$ per day. The RDA of $\mathrm{Zn}$ is $11 \mathrm{mg}$ per day for men and $8 \mathrm{mg}$ for women, and the RDA of Mn for men and woman is $2.3 \mathrm{mg}$ and $1.8 \mathrm{mg}$ per day, respectively (Institute of Medicine US, 2001). Micronutrient deficiency in humans occurs in all regions of the world (Martinez-Ballesta et al., 2010; Nieder et al., 2018). Plant based food provide most of the micronutrients required for a healthy human diet. Soil is the main source of micronutrients for plants. The micronutrient availability to plants depends on their chemical form, soil properties, particularly $\mathrm{pH}$ and organic matter content, and environmental conditions. Abiotic stresses such as drought or extreme temperatures affect the mineral element content in the field growing crops (Tack, 2014). Micronutrient deficiencies in plants not only limit crop productivity but also affect crop quality as a human food. In sustainable agriculture, the most environmentally-friendly way to increase the amount of essential human micronutrient in plant based food is breeding of genotypes that have a naturally higher micronutrient content and proper agronomic practices (Frossard et al., 2000; Khoshgoftarmanesh et al., 2010; Haynes et al., 2012). 
In modern plant production focusing on high quality of plant based food, biostimulants have been gaining increasing importance (Calvo et al., 2014; Bulgari et al., 2015). Titanium is categorized as a plant growth stimulant. Water-soluble chelate forms of titanium, such as ascorbate, citrate or malate applied via roots or leaves in low concentrations have a beneficial effect on various plant physiological processes and increase the crop yield, and can improve the crop quality. The beneficial effect of titanium is a result, among others, of its interaction with other elements, primarily with $\mathrm{Fe}$ (Du et al., 2010; Bacilieri et al., 2017; Lyu et al., 2017). Titanium foliar application resulted in an increase in $\mathrm{Fe}, \mathrm{Cu}$ and $\mathrm{Zn}$ contents in bean (Ram et al., 1983), Fe in red pepper and in barley grain (Carvajal and Alcaraz, 1995; Tlustoš et al., 2005) and Zn in wheat grain (Tlustoš et al., 2005). To date, few studies have been focused on the effect of titanium on micronutrient contents in root and tuber plants. Titanium foliar application resulted in an increase in $\mathrm{Zn}$ content and a decrease in Fe and Mn contents in potato tuber (Tlustoš et al., 2005; Mystkowska, 2018).

Potato (Solanum tuberosum L.) is a one of the most important crops ensuring food security in the world and a valuable source of nutritional compounds in the human diet. Potatoes do not contain a large amount of micronutrients, with the exception of Fe, however, due to the amount consumed per capitata, they can make up a significant source of micronutrients in the human diet (Burgos et al., 2007; Haynes et al., 2012; Tack, 2014). Consumption of $100 \mathrm{~g}$ potatoes can provide $12-15 \%$ of the Recommended Dietary Allowence (RDA) of iron, 6-8\% of manganese and 2-3\% of zinc (Leszczyński, 2012; Wierzbicka, 2012). Micronutrient contents in potato tubers are affected by a cultivar, environmental conditions and agronomical practices (Rivero et al., 2003; MartinezBallesta et al., 2010; Wierzbicka, 2012; Lombardo et al., 2014; Tack, 2014; Wierzbowska et al., 2018). In the our study it was hypothesised that the stimulation of potato plant growth by titanium foliar application would contribute to an increase in essential human micronutrient content in tubers. It was assumed that the potato response to titanium depend on the dose and date of titanium application and that the results of titanium application depends on the potato cultivar and environment in which the potato grow. The aim of the study was to determine the effect of the dose and date of titanium foliar application on essential human micronutrient contents in early crop potato tubers.

\section{Materials and Methods}

\section{Plant material and experimental design}

The study material included tubers of two very early potato cultivars 'Lord' and 'Miłek' (Polish cultivars which are registered on the Common Catalogue of Varieties of Agricultural Plant Species CCV) obtained from a field experiment carried out in central eastern Poland $\left(52^{\circ} 03^{\prime} \mathrm{N} ; 2^{\circ} 33^{\prime} \mathrm{E}\right)$ during three growing seasons $(2009,2010$ and 2012) with a varied the weather conditions (Table 1). Over the three-year period of the study, the mean air temperatures in the beginning period of potato growth were above the longterm average. In 2009 total precipitation in potato growing season was above and in 2010 and 2012 similar to long-term average, however, unevently distributed during potato growth period (Wadas and Kalinowski, 2018). The field experiment was carried out on Luvisol with an acidic-to-slightly-acid reaction, with a low content of available $\mathrm{Zn}$, a medium content of Mn as well as a high content of Fe (Table 2).

The titanium (Ti) source was the mineral plant growth stimulant Tytanit ${ }^{\circledR}$ (8.5 g Ti per litre, $0.8 \% \mathrm{~m} / \mathrm{m}$, in the form of Ti-ascorbate) produced by INTERMAG Ltd., Poland. The 
effect of dose $\left(0.2 \mathrm{~L} \mathrm{ha}^{-1}\right.$ and $\left.0.4 \mathrm{~L} \mathrm{ha}^{-1}\right)$ and date of Tytanit ${ }^{\circledR}$ application (a single foliar application at the leaf development stage - $\mathrm{BBCH} 14-16$ or at the tuber formation stage - BBCH 41-43, and a double foliar application at the leaf development and tuber formation stages - BBCH 14-16 and BBCH 41-43) on the essential human micronutrient and titanium contents in early crop potato tubers was investigated. The field experiment was established in a split-block-split-plot design with a control object without Tytanit ${ }^{\circledR}$ in three replications. Potato cultivation was carried out according to common agronomical practice. In successive years, 6-week pre-sprouted seed potatoes were planted on $15^{\text {th }}$, $13^{\text {th }}$ and $12^{\text {th }}$ April. Potatoes were harvested 75 days after planting (the end of June). For laboratory studies 50 different-sized tubers of each treatment were taken.

Table 1. Selected soil chemical properties in the experimental site

\begin{tabular}{c|c|c|c|c|c|c|c|c}
\hline \multirow{2}{*}{ Years } & \multirow{2}{*}{$\begin{array}{c}\text { Corg } \\
\left(\mathbf{g ~ k g}^{-1}\right)\end{array}$} & \multirow{2}{*}{$\mathbf{p H}$} & \multicolumn{6}{|c}{ Available forms (mg kg-1 of soil) } \\
\cline { 4 - 8 } & & $\mathbf{P}$ & $\mathbf{K}$ & $\mathbf{M g}$ & $\mathbf{Z n}$ & $\mathbf{M n}$ & $\mathbf{F e}$ \\
\hline 2009 & 8.7 & 6.6 & 128 & 104 & 38 & 7.2 & 95.3 & 730 \\
2010 & 14.2 & 6.1 & 88 & 120 & 45 & 9.3 & 79.2 & 550 \\
2012 & 7.9 & 4.7 & 122 & 208 & 22 & 4.1 & 65.2 & 645 \\
\hline
\end{tabular}

Table 2. Mean air temperature and precipitation total in the potato growing season

\begin{tabular}{c|c|c|c|c|c|c}
\hline \multirow{2}{*}{ Years } & \multicolumn{3}{|c|}{ Temperature $\left({ }^{\circ} \mathbf{C}\right)$} & \multicolumn{3}{c}{ Rainfalls (mm) } \\
\cline { 2 - 7 } & April & May & June & April & May & June \\
\hline 2009 & 10.3 & 12.9 & 15.7 & 8.1 & 68.9 & 145.2 \\
2010 & 8.9 & 14.0 & 17.4 & 10.7 & 93.2 & 62.6 \\
2012 & 8.9 & 14.6 & 16.3 & 29.9 & 53.4 & 76.2 \\
Many-year mean & 8.1 & 11.9 & 16.7 & 45.5 & 49.7 & 63.0 \\
$(1981-2005)$ & & & & &
\end{tabular}

\section{Chemical analysis}

The contents of $\mathrm{Fe}, \mathrm{Zn}, \mathrm{Mn}$ and $\mathrm{Ti}$ were determining by atomic emission spectroscopy with the inductively-coupled plasma method (ICP-AES) following previous mineralization of potato tuber samples. One gram of the oven-dried potato sample was oxidized dry at $450-550^{\circ} \mathrm{C}$ in a muffle furnace, and the ash was dissolved in a $10 \% \mathrm{HCl}$. The total contents of $\mathrm{Fe}, \mathrm{Zn}, \mathrm{Mn}$ and $\mathrm{Ti}$ were determined on an atomic emission spectrometer with inductively-coupled plasma Optima 3200 RL produced by PerkinElmer. All assays were performed in duplicate and the mean results were expressed in milligrams per kilogram of potato tuber dry matter (DM).

\section{Statistical analysis}

The results of the study were analysed statistically by means of analysis of variance (ANOVA) for the split-block-split-plot design. The analysis of the results was conducted using orthogonal contrast to compare the control object without Tytanit ${ }^{\circledR}$ with the remaining objects. The significance of differences was verified using Tukey's test at $\mathrm{p} \leq 0.05$. 


\section{Results}

Tytanit ${ }^{\circledR}$ application caused an increase in the content of $\mathrm{Fe}, \mathrm{Mn}$ and $\mathrm{Ti}$ in potato tuber but did not affect the content of Zn (Table 3). Over the three-year period of the study, the Fe content in tubers was higher, on average, by $6.150 \mathrm{mg} \mathrm{kg}^{-1}$ of DM, Mn by $0.409 \mathrm{mg}$ $\mathrm{kg}^{-1}$ of DM and Ti by $0.364 \mathrm{mg} \mathrm{kg}^{-1}$ of DM compared to the cultivation without the growth stimulant. Tytanium foliar application had a greatest effect on the Mn content in tubers in 2012 with the lowest content of available Mn in soil (data not presented). In that year, with the Tytanit ${ }^{\circledR}$ application, the Mn content in tubers was higher by $0.939 \mathrm{mg} \mathrm{kg}^{-1}$ of $\mathrm{DM}$, on average, compared to the control object without the growth stimulant.

Table 3. Effect of Tytanit $\AA$ on micronutrient contents in potato tubers ( $\mathrm{mg} \mathrm{kg}^{-1}$ of DM); mean for years and cultivars

\begin{tabular}{c|c|c|c|c}
\hline Treatment & Fe & Zn & Mn & Ti \\
\hline Without Tytanit ${ }^{\circledR}$ & $73.33 \mathrm{~b}$ & $24.72 \mathrm{a}$ & $6.774 \mathrm{~b}$ & $1.803 \mathrm{~b}$ \\
With Tytanit ${ }^{\circledR}$ & $79.48 \mathrm{a}$ & $24.64 \mathrm{a}$ & $7.183 \mathrm{a}$ & $2.167 \mathrm{a}$ \\
\hline
\end{tabular}

Means within columns followed by the same letters do not differ significantly at $\mathrm{p} \leq 0.05$

The Tytanit ${ }^{\circledR}$ dose did not affect the content of Fe in tubers of either tested potato cultivars (Table 4). The study demonstrated a significant interaction effect of the potato cultivar and the dose of Tytanit ${ }^{\circledR}$ on the Mn content in tubers. The dose of Tytanit $\AA$ application had a significant effect on the Mn content only in the 'Lord' cultivar tubers (Table 4).

Table 4. Effect of Tytanit ${ }^{\circledR}$ dose on $\mathrm{Fe}, \mathrm{Mn}$ and Ti contents in potato tubers in relation to cultivar ( $\mathrm{mg} \mathrm{kg}^{-1}$ of DM); mean for years and date of Tytanit ${ }^{\circledR}$ application

\begin{tabular}{c|cc|cc|cc}
\hline \multirow{2}{*}{ Tytanit ${ }^{\circledR}$ dose } & \multicolumn{2}{|c|}{ Fe } & \multicolumn{2}{c|}{ Mn } & \multicolumn{2}{c}{ Ti } \\
\cline { 2 - 7 } & Lord & Milek & Lord & Milek & Lord & Milek \\
\hline $0.2 \mathrm{~L} \mathrm{ha}^{-1}$ & $81.74 \mathrm{a}$ & $77.97 \mathrm{a}$ & $7.293 \mathrm{a}$ & $7.291 \mathrm{a}$ & $2.293 \mathrm{a}$ & $2.239 \mathrm{a}$ \\
$0.4 \mathrm{~L} \mathrm{ha}^{-1}$ & $80.38 \mathrm{a}$ & $77.82 \mathrm{a}$ & $6.808 \mathrm{~b}$ & $7.339 \mathrm{a}$ & $2.096 \mathrm{~b}$ & $2.041 \mathrm{a}$ \\
\hline
\end{tabular}

Means within columns followed by the same letters do not differ significantly at $p \leq 0.05$

Following the application of $0.2 \mathrm{~L} \mathrm{ha}^{-1}$ of Tytanit ${ }^{\circledR}$, the Mn content in tubers of 'Lord' was higher, on average, by $0.485 \mathrm{mg} \mathrm{kg}^{-1}$ of DM compared to the dose of $0.4 \mathrm{~L} \mathrm{ha}^{-1}$. The Tytanit ${ }^{\circledR}$ dose had the greatest effect on the Mn content in tubers of 'Lord' in 2012 with the lowest content of available manganese in soil (data not presented). In that year, following the application of $0.2 \mathrm{~L} \mathrm{ha}^{-1}$ of Tytanit ${ }^{\circledR}$, the manganese content in tubers of this cultivar was higher, on average, by $1.338 \mathrm{mg} \mathrm{kg}^{-1}$ of DM compared to the dose of 0.4 $\mathrm{L} \mathrm{ha}^{-1}$. The dose of Tytanit ${ }^{\circledR}$ application had a significant effect on the Ti content in tubers of both tested potato cultivars (Table 4). After the application of $0.2 \mathrm{~L} \mathrm{ha}^{-1}$ of Tytanit ${ }^{\circ}$, the Ti content in tubers was higher, on average, by $0.198 \mathrm{mg} \mathrm{kg}^{-1}$ of DM compared to the dose of $0.4 \mathrm{~L} \mathrm{ha}^{-1}$. The difference was greatest in the warm and moderately wet growing season of 2012 (Table 5). In that year, after the application of $0.2 \mathrm{~L} \mathrm{ha}^{-1}$ of Tytanit $\AA$, the Ti content in tubers was higher, on average, by $0.455 \mathrm{mg} \mathrm{kg}^{-1}$ of DM. 
Table 5. Effect of Tytanit ${ }^{\circledR}$ dose on $\mathrm{Mn}$ and Ti content in potato tubers in relation to year ( $m g \mathrm{~kg}^{-1}$ of DM); mean for cultivars and date of Tytanit ${ }^{\circledR}$ application

\begin{tabular}{c|ccc|ccc}
\hline \multirow{2}{*}{ Tytanit ${ }^{\circledR}$ dose } & \multicolumn{3}{|c|}{ Mn } & \multicolumn{3}{c}{ Ti } \\
\cline { 2 - 7 } & $\mathbf{2 0 0 9}$ & $\mathbf{2 0 1 0}$ & $\mathbf{2 0 1 2}$ & $\mathbf{2 0 0 9}$ & $\mathbf{2 0 1 0}$ & $\mathbf{2 0 1 2}$ \\
\hline $0.2 \mathrm{~L} \mathrm{ha}^{-1}$ & $7.562 \mathrm{a}$ & $6.901 \mathrm{a}$ & $7.413 \mathrm{a}$ & $1.557 \mathrm{a}$ & $3.004 \mathrm{a}$ & $2.237 \mathrm{a}$ \\
$0.4 \mathrm{~L} \mathrm{ha}^{-1}$ & $7.194 \mathrm{a}$ & $7.139 \mathrm{a}$ & $6.887 \mathrm{a}$ & $1.413 \mathrm{a}$ & $3.011 \mathrm{a}$ & $1.782 \mathrm{~b}$ \\
\hline
\end{tabular}

Means within columns followed by the same letters do not differ significantly at $\mathrm{p} \leq 0.05$

The date of Tytanit ${ }^{\circledR}$ application had a slight effect on the content of Fe and $\mathrm{Mn}$ in tubers of both tested potato cultivars (Table 6 ). The date of Tytanit ${ }^{\circledR}$ application had a significant effect on the Mn content only in 2012 with the lowest content of available Mn in soil (Table 7).

Table 6. Effect of date of Tytanit ${ }^{\circledR}$ application on Fe, Mn and Ti contents in potato tubers in relation to cultivar ( $\mathrm{mg} \mathrm{kg}^{-1}$ of DM); mean for years and Tytanit ${ }^{\circledR}$ dose

\begin{tabular}{c|cc|cc|cc}
\hline \multirow{2}{*}{ Date of Tytanit® application } & \multicolumn{2}{|c|}{ Fe } & \multicolumn{2}{c|}{ Mn } & \multicolumn{2}{c}{ Ti } \\
\cline { 2 - 7 } & Lord & Milek & Lord & Milek & Lord & Milek \\
\hline Leaf development stage & $81.72 \mathrm{a}$ & $76.70 \mathrm{a}$ & $6.972 \mathrm{a}$ & $7.040 \mathrm{a}$ & $2.010 \mathrm{~b}$ & $1.829 \mathrm{c}$ \\
Tuber formation stage & $80.08 \mathrm{a}$ & $78.40 \mathrm{a}$ & $6.864 \mathrm{a}$ & $7.360 \mathrm{a}$ & $2.088 \mathrm{~b}$ & $2.165 \mathrm{~b}$ \\
$\begin{array}{c}\text { Leaf development and } \\
\text { tuber formation stages }\end{array}$ & $81.38 \mathrm{a}$ & $78.60 \mathrm{a}$ & $7.315 \mathrm{a}$ & $7.545 \mathrm{a}$ & $2.485 \mathrm{a}$ & $2.425 \mathrm{a}$ \\
\hline
\end{tabular}

Means within columns followed by the same letters do not differ significantly at $p \leq 0.05$

Table 7. Effect of date of Tytanit ${ }^{\circledR}$ application on Mn and Ti content in potato tubers in relation to year ( $\mathrm{mg} \mathrm{kg}^{-1}$ of DM); mean for cultivars and Tytanit ${ }^{\circledR}$ dose

\begin{tabular}{c|ccc|ccc}
\hline \multirow{2}{*}{ Date of Tytanit ${ }^{\circledR}$ application } & \multicolumn{3}{|c|}{ Mn } & \multicolumn{3}{c}{ Ti } \\
\cline { 2 - 7 } & $\mathbf{2 0 0 9}$ & $\mathbf{2 0 1 0}$ & $\mathbf{2 0 1 2}$ & $\mathbf{2 0 0 9}$ & $\mathbf{2 0 1 0}$ & $\mathbf{2 0 1 2}$ \\
\hline Leaf development stage & $7.418 \mathrm{ab}$ & $6.963 \mathrm{a}$ & $6.673 \mathrm{~b}$ & $1.303 \mathrm{~b}$ & $2.702 \mathrm{~b}$ & $1.755 \mathrm{~b}$ \\
Tuber formation stage & $6.932 \mathrm{~b}$ & $6.808 \mathrm{a}$ & $7.596 \mathrm{a}$ & $1.503 \mathrm{ab}$ & $2.679 \mathrm{~b}$ & $2.195 \mathrm{a}$ \\
$\begin{array}{c}\text { Leaf development and } \\
\text { tuber formation stages }\end{array}$ & $7.784 \mathrm{a}$ & $7.289 \mathrm{a}$ & $7.218 \mathrm{ab}$ & $1.649 \mathrm{a}$ & $3.642 \mathrm{a}$ & $2.080 \mathrm{a}$ \\
\hline
\end{tabular}

Means within columns followed by the same letters do not differ significantly at $p \leq 0.05$

In that year, with the single Tytanit ${ }^{\circledR}$ application in the leaf development stage the Mn content in tubers was lower, on average, by $0.959 \mathrm{mg} \mathrm{kg}^{-1}$ of DM as compared with the single application in the tuber formation stage. With double Tytanit ${ }^{\circledR}$ application, in the leaf development stage and with a repeated treatment in the tuber formation stage, the Mn content in tuber was similar to the single treatment in the tuber formation stage. The $\mathrm{Ti}$ content in tuber was greatest with double Tytanit ${ }^{\circledR}$ application (Table 6). With double Tytanit ${ }^{\circledR}$ application, the Ti content in tuber was higher, on average, by $0.535 \mathrm{mg} \mathrm{kg}^{-1}$ of DM compared to the single treatment in the leaf development stage and by $0.325 \mathrm{mg} \mathrm{kg}^{-}$ ${ }^{1}$ of DM compared to the treatment in the tuber formation stage. The differences were greatest in 2010 with heavy rainfall in May and the periodically water shortage in June, $0.940 \mathrm{mg} \mathrm{kg}^{-1}$ and $0.963 \mathrm{mg} \mathrm{kg}^{-1}$ of DM, respectively (Table 7). The performed study demonstrated a significant interaction effect of the dose and date of Tytanit ${ }^{\circledR}$ application 
on the Mn and Ti contents in tubers (Table 8). The content of Mn was greatest with a single Tytanit ${ }^{\circledR}$ application in the tuber formation stage at the dose of $0.2 \mathrm{~L} \mathrm{ha}^{-1}$, whereas the content of $\mathrm{Ti}$ was greatest with the double Tytanit ${ }^{\circledR}$ application, in the leaf development stage and with repeated treatment in the tuber formation stage at a dose of $0.2 \mathrm{~L} \mathrm{ha}^{-1}$ in each treatment.

Table 8. Effect of dose and date of Tytanit ${ }^{\circledR}$ application on Mn and Ti content in potato tubers ( $m g \mathrm{~kg}^{-1}$ of DM); mean for years and cultivars

\begin{tabular}{|c|c|c|c|c|}
\hline \multirow{3}{*}{ Date of Tytanit ${ }^{\circledR}$ application } & \multirow{2}{*}{\multicolumn{2}{|c|}{$\begin{array}{c}\text { Mn } \\
\text { Tytanit }{ }^{\circledR} \text { dose }\end{array}$}} & \multirow{2}{*}{\multicolumn{2}{|c|}{$\begin{array}{c}\text { Ti } \\
\text { Tytanit }{ }^{\circledR} \text { dose }\end{array}$}} \\
\hline & & & & \\
\hline & $0.2 \mathrm{~L} \mathrm{ha}^{-1}$ & $0.4 \mathrm{~L} \mathrm{ha}^{-1}$ & $0.2 \mathrm{~L} \mathrm{ha}^{-1}$ & $0.4 \mathrm{~L} \mathrm{ha}^{-1}$ \\
\hline Leaf development stage & $6.777 \mathrm{~b}$ & $7.235 \mathrm{ab}$ & $1.901 \mathrm{c}$ & $1.938 b$ \\
\hline Tuber formation stage & $7.567 \mathrm{a}$ & $6.657 b$ & $2.200 \mathrm{~b}$ & $2.060 \mathrm{ab}$ \\
\hline $\begin{array}{l}\text { Leaf development and } \\
\text { tuber formation stages }\end{array}$ & $7.531 \mathrm{a}$ & $7.329 \mathrm{a}$ & $2.700 \mathrm{a}$ & $2.210 \mathrm{a}$ \\
\hline
\end{tabular}

Means within columns followed by the same letters do not differ significantly at $p \leq 0.05$

The content of examined micronutrients in the potato tuber depended to a great extent on the cultivar and environment conditions during the potato growing season (Table 9). Regardless of the treatment, 'Lord' tubers contained more Fe, on average, by $3.20 \mathrm{mg} \mathrm{kg}^{\text {- }}$ ${ }^{1}$ of DM and $\mathrm{Zn}$ by $2.50 \mathrm{mg} \mathrm{kg}^{-1}$ of DM and less Mn by $0.30 \mathrm{mg} \mathrm{kg}^{-1}$ of DM than tubers of 'Miłek'. The content of Ti in tubers of both cultivars was similar. The most $\mathrm{Zn}$ and Mn were accumulated by potato tubers in the cool and very moist growing season of 2009 , whereas the most $\mathrm{Fe}$ and $\mathrm{Ti}$ were accumulated in tubers in 2010, with havy rainfall in May and the periodically water shortage in June.

Table 9. Micronutrient contents in potato tubers in relation to cultivar and year ( $\mathrm{mg} \mathrm{kg}^{-1}$ of $D M)$; mean for objects with and without Tytanit ${ }^{\circledR}$

\begin{tabular}{ccccc}
\hline Cultivar and year & Fe & Zn & Mn & Ti \\
\hline Lord & $80.20 \mathrm{a}$ & $25.90 \mathrm{a}$ & $6.974 \mathrm{~b}$ & $2.152 \mathrm{a}$ \\
Miłek & $77.20 \mathrm{~b}$ & $23.40 \mathrm{~b}$ & $7.274 \mathrm{a}$ & $2.078 \mathrm{a}$ \\
\hline 2009 & $83.12 \mathrm{~b}$ & $30.06 \mathrm{a}$ & $7.354 \mathrm{a}$ & $1.420 \mathrm{c}$ \\
2010 & $94.90 \mathrm{a}$ & $22.04 \mathrm{~b}$ & $7.003 \mathrm{~b}$ & $2.958 \mathrm{a}$ \\
2012 & $57.78 \mathrm{c}$ & $21.87 \mathrm{c}$ & $7.016 \mathrm{~b}$ & $1.967 \mathrm{~b}$ \\
\hline
\end{tabular}

Means within columns followed by the same letters do not differ significantly at $\mathrm{p} \leq 0.05$

Results presented in this study demonstrate that a typical meal with $200 \mathrm{~g}$ of boiled potatoes (at least three medium-sized tubers) from the cultivation without Tytanit ${ }^{\circledR}$ provided up to $32 \%$ of the Recommended Dietary Allowance (RDA) of Fe for men and postmenopausal women and up to $14 \%$ of the RDA for premenopausal women, and up to $10 \%$ of the RDA of $\mathrm{Mn}$ for men and $13 \%$ for woman. Potatoes derived from the cultivation with Tytanit ${ }^{\circledR}$ provided up to $35 \%$ of the RDA of $\mathrm{Fe}$ for men and postmenopausal women and up to $16 \%$ of the RDA for premenopausal women, and up to $11 \%$ of the RDA of Mn for men and $14 \%$ for woman. Potatoes from the cultivation with or without Tytanit巴 provided up to $8 \%$ of RDA of $\mathrm{Zn}$ for men and $11 \%$ for woman. 


\section{Discussion}

The beneficial effect of titanium on plant metabolism include, among others, an increase in the uptake of other elements (Du et al., 2010; Lyu et al., 2017; Bacilieri et al., 2017). A foliar application of Ti during potato growth increases the activity of peroxidase, however, during tuberization the activity of superoxide dismutase and peroxidase. Tytanit ${ }^{\circledR}$ did not affect the content of dry matter and nitrogen, phosphorus, potassium, calcium, magnesium or sulphur in potato tubers. Following Tytanit ${ }^{\circledR}$ application, there was only an increase in sodium content (Wadas and Kalinowski, 2018). The application of Ti favored Fe uptake (Bacilieri et al., 2017), which was confirmed in the present study. A single or a double Tytanit ${ }^{\circledR}$ (Ti-ascorbate) application during potato grown on Luvisol with an acidic-to-slightly-acid reaction at the dose of $0.2 \mathrm{~L} \mathrm{ha}^{-1}$ or $0.4 \mathrm{~L} \mathrm{ha}^{-1}$ in each treatment caused an increase in the contents of $\mathrm{Fe}, \mathrm{Mn}$ and $\mathrm{Ti}$ in early crop tubers of very early 'Lord' and 'Miłek' cultivars. Titanium foliar application did not affect the content of Zn. A study carried out in the Czech Republic showed that titanium foliar applied three times in the form of Ti-citrate during potato grown on Chernozem with an alcaline reaction (at the beginning of June with a plant height of $30 \mathrm{~cm}$ and repeated treatment in two-week intervals) in the dose of $10 \mathrm{~g} \mathrm{Ti} \mathrm{ha}^{-1}$ in each treatment resulted in a slight decrease in $\mathrm{Fe}$ and an increase in the $\mathrm{Zn}$ in mature tubers of 'Cordoba' cultivar (Tlustoš et al., 2005). A study carried out in Poland showed that three times Tytanit $\AA$ application during potato grown on the soil with a slightly-acid or alcaline reaction (beginning of plant flowering, full flowering and after plant flowering) in the dose of $0.2 \mathrm{~L} \mathrm{ha}^{-1}$ in each treatment resulted in a decrease of $\mathrm{Mn}$ and $\mathrm{Fe}$ content in mature tubers of three mediumearly ('Honorata', 'Jelly', 'Tajfun') potato cultivars (Mystkowska, 2018), which was not confirmed in the present study. Titanium application up to a dose of $25.5 \mathrm{~g} \mathrm{Ti} \mathrm{ha}^{-1}$ is not toxic for the potato crop (Bacilieri et al., 2017). A negative correlation was revealed between soil $\mathrm{pH}$ and iron and manganese concentration in potato tubers (Rogóż, 2009; Tack, 2014), which was confirmed in the present study. Fe and Ti have sinergistic and antagonistic relationships (Lyu et al., 2017). In the presented studies titanium was applied in the chelate forms as Ti-citrate or Ti-ascorbate. Leaf ability to uptake chelated nutrients is related to various properties of a chelate, such as the molecular weight of the complex, dissociation constant and stability of the complex at various $\mathrm{pH}$ (Wójcik, 2004). The effect of titanium depends on the plant age and the tissue concentration of other minerals (Lyu et al., 2014; Bacilieri et al., 2017). Potato plants uptake mineral elements primarily from the soil solution through their roots. Direct uptake of minerals into the developing tubers across the periderm is also possible, however in a mature tuber it will be limited due to the suberized nature of the periderm (Subramanian et al., 2011). The dose and date of Tytanit ${ }^{\circledR}$ application slightly affected the content of Fe in tubers of both tested potato cultivars and the content of Mn in the 'Miłek' tuber. The Mn content in the 'Lord' tuber was greater with Tytanit ${ }^{\circledR}$ application at the dose of $0.2 \mathrm{~L} \mathrm{ha}^{-1}$. The results showed a differential response of the examined very early potato cultivars to titanium foliar application. The response of crop plants to a foliar supply of nutrients differed between crop species as well as cultivars within the same species (Kannan, 2010), which was confirmed in the present study. The age of the leaf is important for nutrients foliar absorption. The young leaves absorbed more nutrients than the older ones (Wójcik, 2004). This study demonstrated a significant effect of the interaction of the dose and date of Tytanit ${ }^{\circledR}$ application on the Mn and Ti contents in potato tubers. Regardless of the potato cultivar, the content of $\mathrm{Mn}$ was greatest with the single Tytanit ${ }^{\circledR}$ application in the tuber formation stage at the dose of $0.2 \mathrm{~L} \mathrm{ha}^{-1}$, whereas the Ti content was greatest with a double 
Tytanit $\AA$ application during potato grown at the leaf development stage and at the tuber formation stage at a dose of $0.2 \mathrm{~L} \mathrm{ha}^{-1}$ in each treatment. Leaf-absorbed Ti is distributed approximately equally between the leaves and roots (Kelemen et al., 1993; Lyu et al., 2017). The study carried out by other authors, showed a trace amounts of $\mathrm{Ti}$ in potato tuber after foliar application of titanium-containing fertilizers (Ti-ascorbate). The content of $\mathrm{Ti}$ in sugar beet roots was considerably higher. The content of $\mathrm{Ti}$ in the green parts of a plant (leaves, stems) was greater than in the roots or tuber (Świerczewska and Sztuder, 2004). A positive correlation was found between the Fe and Mn content in potato tubers (Wierzbicka, 2012), which was confirmed in the present study. Tytanit ${ }^{\circledR}$ caused an increase in the content of both $\mathrm{Fe}$ and $\mathrm{Mn}$ in early crop potato tubers. An opposite correlation between the Fe and $\mathrm{Mn}$ are in human body; Fe deficiency can increase in $\mathrm{Mn}$ availability (Jędrzejczak, 2004). Following Tytanit ${ }^{\circledR}$ application, the Fe/Mn ratio in the early crop potato tubers $(11.1 / 1)$ was similar to that for potatoes with the cultivation without the growth stimulant (10.8/1), and was on the same level or broader than those reported for mature tubers of early and medium-early potato cultivars (Lombardo et al., 2014; Wierzbowska et al., 2015; Mystkowska, 2018).

The content of $\mathrm{Fe}, \mathrm{Zn}$ or $\mathrm{Mn}$ in potato tubers depended to a great extent on the cultivar and environmental conditions, which was confirmed by other authors (Rivero et al., 2003; Burgos et al., 2007; Haynes et al., 2012; Lombardo et al., 2014; Rivadeneira et al., 2016; Sharma et al., 2017; Wierzbowska et al., 2018). In the present study, 'Lord' tubers contained more Fe and $\mathrm{Zn}$ and less Mn than 'Miłek' tubers grown under the same conditions, although the content of $\mathrm{Ti}$ in tubers of both tested cultivars did not differ significantly. Genotype variation in nutrient uptake from soil is associated with the size of the root system and root morphology (Trehan and Singh, 2013). Nutrient uptake by plants depends on their levels in the soil and phytoavailability. The most significant environmental factors affecting the nutrient uptake by plant are soil moisture and $\mathrm{pH}$. The availability of micronutrients present in a soil solution as cations (e.g. $\mathrm{Fe}^{2+}, \mathrm{Zn}^{2+}$ and $\mathrm{Mn}^{2+}$ ) increases with increasing soil acidity. The potential of roots to uptake mineral elements generally declines in water-stressed plants (Martinez-Ballesta et al., 2010; Trehan and Singh, 2013; Rivadeneira et al., 2016), which was confirmed in the present study. Under drought conditions, the greater presence of oxygen in the soil induces a decrease in the $\mathrm{Fe}^{2+} / \mathrm{Fe}^{3+}$ ratio, leading to a decrease in $\mathrm{Fe}$ available for plants (Silva et al., 2011). Under a limited plant supply with Fe, the application of an appropriate concentration of $\mathrm{Ti}$ may induce the expression of genes related to iron acquisition, enhancing iron uptake (Lyu et al., 2017), which was confirmed in the present study. The most $\mathrm{Ti}$ was contained in potato tubers in the year with the highest air temperature and a heavy rainfall in the leaf development and tuber formation stages. Generally, it is believed that high light intensity and high air temperatures during rapid leaf expansion favours the absorption of mineral nutrients by the leaves. High air humidity also stimulates the absorption of leaf-applied nutrients (Wójcik, 2004), which was confirmed in the present study.

Titanium foliar application may be one approach to increasing the amount of essential human micronutrients in potato tubers. It has been estimated that human body take in about $0.8 \mathrm{mg}$ Ti per day (Kabata-Pendias and Pendias, 1999). The amount of Ti provided with the examined potatoes does not exceed $10 \%$ of the estimated daily intake. 


\section{Conclusions}

This study showed that it is be possible to increase Fe and Mn content in early crop potato tubers by foliar application of an appropriate dose of titanium, particularly under abiotic stress conditions. Following Tytanit ${ }^{\circledR}$ application, the content of $\mathrm{Fe}$ was higher, on average, by $6.150 \mathrm{mg} \mathrm{kg}^{-1}$ of DM and Mn by $0.409 \mathrm{mg} \mathrm{kg}^{-1}$ of DM compared to the cultivation without the growth stimulant. Titanium foliar application did not affect the content of $\mathrm{Zn}$, whereas the content of Ti in tuber was higher, on average, by $0.364 \mathrm{mg} \mathrm{kg}^{-}$ ${ }^{1}$ of DM. The dose and date of Tytanit ${ }^{\circledR}$ application slightly affected the content of $\mathrm{Fe}$ in potato tuber. The content of $\mathrm{Mn}$ was greatest with a single Tytanit ${ }^{\circledR}$ application at the tuber formation stage at the dose of $0.2 \mathrm{~L} \mathrm{ha}^{-1}$, whereas the Ti content in tuber was greatest with a double Tytanit ${ }^{\circledR}$ application during potato growth, at the leaf development stage and with a repeated treatment in the tuber formation stage at the dose of $0.2 \mathrm{~L} \mathrm{ha}^{-1}$ in each treatment. This study showed a differential response of very early potato cultivars to titanium foliar application. So, determination of the possibility of increasing micronutrient contents in potato tubers with foliar application of titanium needs the more researches. Determining of optimal dose and date of titanium application for various potato cultivars is very important in the optimisation of potato production.

Acknowledgements. This study was supported by the Polish Ministry of Science and Higher Education under the statutory activities of the Siedlce University of Natural Sciences and Humanities [grant number 218/05/S].

\section{REFERENCES}

[1] Al-Fartusie, F. S., Mohssan, S. N. (2017): Essential trace elements and their vital roles in human body. - Indian Journal of Advances in Chemical Science 5: 127-136.

[2] Bacilieri, F. S., Vasconcelos, A. C. P., Lana, R. M. Q., Mageste, J. G., Torres, J. L. R. (2017): Titanium (Ti) in plant nutrition - A review. - Australian Journal of Crop Science 11: 382-386. https://doi.org/10.21475/ajcs.17.11.04.pne202.

[3] Bulgari, R., Cocetta, G., Trivellini, A., Vernieri, P., Ferrante, A. (2015): Biostimulants and crop response: a review. - Biological Agriculture \& Horticulture 31: 1-17. https://doi.org/10.1080/01448765.2014.964649.

[4] Burgos, G., Amoros, W., Morote, M., Stangoulis, J., Bonierbale, M. (2007): Iron and zinc concentration of native Andean potato cultivars from a human nutrition perspective. Journal of the Science of Food and Agriculture 87: 668-675. https://doi.org/10.1002/jsfa.2765.

[5] Calvo, P., Nelson, L., Kloepper, J. W. (2014): Agricultural uses of plant biostimulants. Plant and Soil 383: 3-41. https://doi.org/10.1007/s11104-014-2131-8.

[6] Carvajal, M., Alcaraz, C. F. (1995): Effect of Ti(IV) on Fe activity in Capsicum annuum. - Phytochemistry 39: 977-980. https://doi.org/10.1016/0031-9422(95)00095-o.

[7] Du, J., Xu, Z., Li, Z., Su, Y., Chen, Y., Wang, X. (2010): Study progress in titanium nutrient of plants. - Acta Agriculturae Jiangxi 1: 42-44.

[8] Frossard, E., Bucher, M., Mächler, F., Mozafar, A., Hurrell, R. (2000): Potential for increasing the content and bioavailability of $\mathrm{Fe}, \mathrm{Zn}$ and $\mathrm{Ca}$ in plants for human nutrition. Journal of the Science of Food and Agriculture 80: 861-879. https://doi.org/10.1002/(sici)1097-0010(20000515)80:7<861::aid-jsfa601>3.0.co;2-p.

[9] Haynes, K. G., Yencho, G. C., Clough, M. E., Henninger, M. R., Sterrett, S. B. (2012): Genetic variation for potato tuber micronutrient content and implications for 
biofortification of potatoes to reduce micronutrient malnutrition. - American Journal of Potato Research 89: 192-198. https://doi.org/10.1007/s12230-012-9242-7.

[10] Institute of Medicine (US) Panel on Micronutrients (2001): Dietary References Intakes for Vitamin C, vitamin K, Arsenic, Boron, Chromium, Copper, Iodine, Iron, Manganese, Molybdenium, Nickel, Silikon, Vanadium, and Zinc. - Washington (DC), National Academies Press (US). https://doi.org/10.17226/10026.

[11] Jędrzejczak, R. (2004): Iron and manganese in food. - Roczniki PZH 55, Suplement: 1320. (in Polish).

[12] Kabata-Pendias, A., Pendias, H. (1999): Biogeochemistry of trace elements. - Polish Scientific Publishers PWN, Warsaw. (in Polish).

[13] Kannan, S. (2010): Foliar fertilization for sustainable crop production. - In: Lichtfouse, E. (ed.) Genetic Engineering, Biofertilisation, Soil Quality and Organic Farming. Sustainable Agriculture Reviews 4. Springer, Dordrecht: 371-402. https://doi.org/10.1007/978-90-4818741-6_13.

[14] Kelemen, G., Keresztes, A., Bacsy, E., Feher, M., Fodor, P., Pais, I., Veto, L. J., Ernst, W. H. O., Verloo, M. (1993): Distribution and intracellular-localization of titanium in plants after titanium treatment. - Food Structure 12: 67-72.

[15] Khoshgoftarmanesh, A. H., Schulin, R., Chaney, R. L., Daneshbakhsh, B., Afyuni, M. (2010): Micronutrient-efficient genotypes for crop yield and nutritional quality in sustainable agriculture. A review. - Agronomy for Sustainable Development 30: 83-107. https://doi.org/10.1051/agro/2009017.

[16] Leszczyński, W. (2012): Nutrition value of potato and potato products. - Biuletyn IHAR 266: 5-20. (in Polish).

[17] Lombaro, S., Pandino, G., Mauromicale, G. (2014): The mineral profile in organically and conventionally grown "early" crop potato tubers. - Scientia Horticulturae 167: 169-173.

[18] Lyu, S., Wei, X., Chen, J., Wang, C., Wang, X., Pan, D. (2017): Titanium as a beneficial element for crop production. - Frontiers in Plant Science 8: 597. https://doi.org/10.3389/fpls.2017.00597.

[19] Martínez-Ballesta, M. C., Dominguez-Perles, R., Moreno, D. A., Muries, B., AlcarazLópez, C., Bastías, E., García-Viguera, C., Carvajal, M. (2010): Minerals in plant food: effect of agricultural practices and role in human health. A review. - Agronomy for Sustainable Development 30: 295-309. https://doi.org/10.1051/agro/2009022.

[20] Mystkowska, I. (2018): The content of iron and manganese in potato tubers treated with biostimulators and their nutritional value. - Applied Ecology and Environmental Research 16: 6633-6641. https://doi.org/10.15666/aeer/1605_66336641.

[21] Nieder, R., Benbi, D. K., Reichl, F. X. (2018): Microelements and their role in human health. - In: Soil components and human health. Springer, Dordrecht: 317-374. https://doi.org/10.1007/978-94-024-1222-2_7.

[22] Ram, N., Verloo, M., Cottenie, A. (1983): Response of bean to foliar spray of titanium. Plant and Soil 73: 285-290. https://doi.org/10.1007/bf02197724.

[23] Rivadeneira, J., Ortega, D., Morales, V., Monteros, C., Cuesta, X. (2016): Effect of interaction genotype by environment in the content of iron, zinc and vitamin $\mathrm{C}$ in potato tuber (Solanum sp.). - Revista Latinoamericana de la Papa 20: 32-45.

[24] Rivero, R. C., Hernández, P. S., Rodriguez, E. M. R., Martin, J. D., Romero, C. D. (2003): Mineral concentrations in cultivars of potatoes. - Food Chemistry 83: 247-253. https://doi.org/10.1016/s0308-8146(03)00087-6.

[25] Rogóż, A. (2009): Trace element content in soils and in selected root crops. Part II. Manganese and iron content. - Zeszyty Problemowe Postępów Nauk Rolniczych 541: 365373. (in Polish).

[26] Sharma, J., Dalamu Sharma, V., Dua, V. K., Gupta, V. K., Kumar, D. (2017): Variations in micronutrient content in tubers of Indian potato varieties. - Potato Journal 44: 101-109.

[27] Silva, E. C., Nogueira, R. J. M. C., Silva, M. A., Albuquerque, M. B. (2011): Drought stress and plant nutrition. - Plant Stress 5, Special Issue 1: 32-41. 
[28] Soetan, K. O., Olaiya, C. O., Oyewole, O. E. (2010): The importance of mineral elements for humans, domestic animals and plants. - African Journal of Food Science 4: 200-222.

[29] Subramanian, N. K., White, P. J., Broadley, M. R., Ramsay, G. (2011): The threedimensional distribution of minerals in potato tubers. - Annals of Botany 107: 681-691. https://doi.org/10.1093/aob/mcr009.

[30] Świerczewska, M., Sztuder, H. (2004): Foliar application of the micronutrient compounds containing titanium. - Zeszyty Problemowe Postępów Nauk Rolniczych 502: 371-376. (in Polish).

[31] Tack, F. M. G. (2014): Trace elements in potato. - Potato Research 57: 311-325. https://doi.org/10.1007/s11540-014-9268-y.

[32] Tlustoš, P., Cígler, M., Hrubý, M., Kužel, J., Száková, J., Balík, J. (2005): The role of titanium in biomass production and its influence on essential elements contents in the field growing crops. - Plant Soil and Environment 51: 19-25. https://doi.org/10.17221/3551-pse.

[33] Trehan, S. P., Singh, B. P. (2013): Nutrient efficiency of different crop species and potato varieties - in retrospect and prospect. - Potato Journal 40: 1-21.

[34] Wadas, W., Kalinowski, K. (2018): Effect of Tytanit ${ }^{\circledR}$ on the dry matter and macroelement contents in potato tuber. Journal of Central European Agriculture 19(3): 557-570. https://doi.org/10.5513/jcea01/19.3.1996.

[35] Welch, R. M. (2002): The impact of mineral nutrients in food crops on global human health. - Plant and Soil 247: 83-90.

[36] Wierzbicka, A. (2012): Mineral content of potato tubers grown in the organic system, their nutritional value and interaction. - Journal of Research and Application in Agricultural Engineering 57: 188-192. (in Polish).

[37] Wierzbowska, J., Cwalina-Ambroziak, B., Bowszys, T., Głosek-Sobieraj, M., MackiewiczWalec, E. (2015): Content of microelements in tubers of potato treated with biostimulators. - Polish Journal of Natural Science 30: 225-234.

[38] Wierzbowska, J., Rychcik, B., Światty, A. (2018): The effect of different production system on the content of micronutrients and trace elements in potato tuber. - Acta Agriculturae Scandinavica, Section B - Soil and Plant Science 68: 701-708. https://doi.org/10.1080/09064710.2018.1466908.

[39] Wójcik, P. (2004): Uptake of mineral nutrients from foliar fertilization (Review). - Journal of Fruit and Ornamental Plant Research 12 (Special Issue): 201-218. 